\title{
Intercultural Relations among Ukrainian Immigrants Living in Portugal ${ }^{*}$
}

\section{Relaciones interculturales entre inmigrantes ucranianos residentes en} Portugal

Received: 07 November 2017 | Accepted: 01 November 2019

\author{
FÉlIx Neto ${ }^{\mathrm{a}}$ \\ Universidade do Porto, Portugal \\ ORCID: http://orcid.org/0000-0003-0112-880X
}

a Correspondence author. Email: fneto@fpce.up.pt

How to cite: Neto, F. (2019). Intercultural relations among Ukrainian immigrants living in Portugal. Universitas Psychologica, 18(5), 1-11. https://doi.org/1 0.11144/Javeriana.upsy18-5.irau

\begin{abstract}
The purpose of this research was to test specific predictions based on three general hypotheses: the integration hypothesis, the contact hypothesis, and the multiculturalism hypothesis. The sample included 218 Ukrainian immigrants with an average of 39 years. The average length of time residing in Portugal was 10 years. As regards the integration hypothesis, psychological adaptation and intercultural adaptation were predicted by integration, while sociocultural adaptation was only predicted by marginalization. Thus, the integration hypothesis was partially supported for Ukrainian immigrants living in Portugal. The contact hypothesis tended to be supported, as intercultural contact was predicted by higher positive attitudes toward Portuguese, and assimilation. However, integration has not emerged as a significant predictor of intercultural contact. This sample displayed a relatively low level of perceived discrimination. In line with the multiculturalism hypothesis, perceived discrimination was negatively related to tolerance, attitude towards Portuguese, attitude towards other immigrants, and positively related to preference for separation and marginalization. Findings are discussed considering the existing literature.

Keywords

acculturation strategies; adaptation; intercultural contact; perceived discrimination;
\end{abstract} Ukrainian migrants.

\section{RESUMEN}

El objetivo de esta investigación fue analizar predicciones específicas basadas en tres hipótesis: la hipótesis de integración, la hipótesis del contacto y la hipótesis del multiculturalismo. La muestra incluyó 218 inmigrantes ucranianos con una media de edad de 39 años. El tiempo medio de residencia en Portugal fue de 10 años. De acuerdo a la hipótesis de integración, las adaptaciones psicológica e intercultural eran predichas por integración, mientras que la adaptación sociocultural era predicha únicamente por marginación. De este modo, la hipótesis de integración fue parcialmente apoyada para los inmigrantes ucranianos residentes en Portugal. La hipótesis del contacto fue confirmada, ya que el contacto intercultural fue predicho por mayores actitudes positivas hacia los portugueses, y por asimilación. Sin embargo, no se encontró que la integración fuera un predictor significativo del contacto intercultural. Esta muestra presentó niveles relativamente bajos de discriminación percibida. En línea con la hipótesis de multiculturalismo, la discriminación 
percibida estaba negativamente relacionada con la tolerancia, la actitud hacia los portugueses, la actitud hacia otros inmigrantes, y positivamente asociada con la preferencia a la separación y la marginación. Se discuten los resultados considerando la literatura existente.

Palabras clave

estrategias de aculturación; adaptación; contacto intercultural; discriminación percibida; inmigrantes ucranianos.

The purpose of this study is to approach a range of issues about the psychological investigation of intercultural relations among Ukrainian immigrants living in Portugal. Namely, we examine specific predictions based on three general hypotheses, the integration hypothesis, the contact hypothesis, and the multiculturalism hypothesis (Berry, 2013). Two core frameworks to intercultural relations are acculturation and adaptation (Ward, Bochner, \& Furnham, 2001; Sam \& Berry, 2016).

\section{Acculturation and adaptation}

An extensive corpus of literature has been devoted to study acculturation and adaptation (Sam \& Berry, 2016; Recker, Milfont, \& Ward, 2017). Acculturation is a dynamic and interactive process. Acculturation is "the process of cultural and psychological change that results following meeting between cultures" (Sam \& Berry, 2010, p. 272). Typically, this process describes and explains minority members' experiences involving the culture of the society of settlement (Neto, 2019). However, majority and minority people within a specific cultural context influence and are influenced by culture contact.

One central concept to intercultural relations is acculturation strategies. Berry's framework of acculturation strategies (Berry, 2017) proposes two main issues: cultural maintenance (the extent to which individuals wish to remain culturally as one has been) and contact and participation (the extent to which people wish to interact daily with members of other groups in the larger society). From these two issues four acculturation strategies can be generated: integration, assimilation, separation and marginalization. Integration presupposes an interest in both the maintenance of one's original culture traits, while at the same time in the daily interactions with other groups. Assimilation occurs when individuals manifest a low interest in the maintenance of one's original culture and an interest in the daily interaction with other groups. Separation presupposes an interest in the maintenance of one's original culture and low interest in the daily interactions with other groups. Finally, marginalization refers to a low interest in both the maintenance of one's original culture and in daily interactions with others. The great majority of the research indicates that the integration strategy is the most adaptive, whereas the marginalization one is the less adaptive. (Berry, 1997; Neto, 2002).

Adaptation involves the outcome of the process of acculturation. It refers to changes people have to make in response to demand in the environment (Berry, 1997). Two kinds of adaptation have been suggested: psychological adaptation and sociocultural adaptation (Ward et al., 2001). The former concerns the psychological and emotional well-being (e.g., well-being and self-esteem). Sometimes it is called "feeling well". Sociocultural adaptation is defined as "intercultural competence with emphasis on behavioral domains" (Ward \& Kennedy, 1999, p. 662). It represents a migrant's ability to acquire culture-specific skills culturally to negotiate intercultural interactions in a new society of settlement. Sometimes it is called "doing well". Intercultural adaptation has more recently been identified as a third form of adaptation, in addition to psychological adaptation and sociocultural adaptation (Berry, 2015). Intercultural adaptation concerns how well people relate with others in a multicultural society (e.g., ethnic attitudes, tolerance). It can be called "relating well".

This work aims to provide some insights into the three core ideas of the intercultural relations among Ukrainian immigrants living in Portugal. According to Serviço de Estrangeiros e Fronteiras (SEF) (2015), the Portuguese Immigration Service, in 2015, Ukrainians were the third largest foreign community in Portugal, 
with 35779 registered citizens. They represented 9\% of the foreign community in Portugal. The Ukrainian immigrants who chose Portugal came across several challenges, such as: the language, the climate, the lack of social support, the cultural differences, the housing, the difficulties in entering the educational and professional system, among other issues (Marques \& Góis, 2008)

\section{Objectives of the present study}

The present study has three objectives related to three general hypotheses: the integration hypothesis, the contact hypothesis and the multiculturalism hypothesis. The first objective is to analyze the extent to which the integration strategy is related to different kinds of adaptation. According to the integration hypothesis (Berry, 1997) the integration strategy is more beneficial for psychological adaptation and sociocultural adaptation than assimilation, separation and, namely, the marginalization strategy.

This hypothesis has been supported by many studies (Ward \& Rana-Deuba, 1999; Brown, Gibbons, \& Hughes, 2013; Abu-Raya \& Sam, 2016; Sam \& Berry, 2016; Ward \& Geeraert, 2016). For example, Berry and Sabatier (2010) investigated second generation immigrants in Canada and France. They showed that integration was related to better adaptation, and marginalization to poorer adaptation. In Portugal, Neto (2010) showed that the integration option had a significant and positive relationship with psychological adaptation and sociocultural adaptation among youths with an immigrant background from Angola, Cape Verde, Guinea-Bissau, India, Mozambique, São-Tomé and East Timor. Nguyen and Bennet-Martinez's (2013) meta-analysis showed integration ("biculturalism" in their terms) has a positive and significant relationships not only with psychological adaptation and sociocultural adaptation but also with domainspecific outcomes such as academic achievement and career success.
Recent research has shown that psychological adaptation and intercultural adaptation were predicted by the integration strategy among Cape Verdean immigrants (Neto, in press). In current study, we analyse whether preference for integration has more benefit for psychological adaptation, sociocultural adaptation and intercultural adaptation than the other acculturation strategies.

As indicator of psychological adaptation we will consider self-esteem which nowadays is omnipresent: "in classrooms and workplaces, sporting events and music recitals, people generally assume that high self-esteem is critical to success in those domains "(Orthy \& Robbins, 2014, p. 381). This construct is widely seen as indicating feelings of personal worth (Rosenberg \& Kaplan, 1982). Coopersmith (1967) defined it as "the evaluation which the individual makes and customarily maintains with regard to himself: it expresses an attitude of approval or disapproval, and indicates the extent to which an individual believes himself to be capable, significant, successful, and worthy" (p. 4). It constitutes a nuclear feature of psychological well-being (Wylie, 1979).

We will consider also an adaptive indicator of intercultural competency, sociocultural adaptation, which is placed within the framework of culture learning (Furnham \& Bochner, 1986; Neto, Wilks, \& Fonseca, 2019). As an indicator of intercultural adaptation we will consider tolerance. Tolerance is an attitude towards social equality, including two components: ethnic tolerance and social egalitarianism (Berry, 2006). Both integration and tolerance are involved in the accepting of other people in the larger society.

The second objective concerns the contact hypothesis (Allport, 1954; Pettigrew \& Tropp, 2011; Zhou, Page-Gould, Aron, Moyer, \& Hewstone, 2019). It proposes that, under most of conditions (namely that of equal status contact) more contact is related to more positive encounters and outcomes. There is clear support for this hypothesis (Pettigrew \& Tropp, 2006): intergroup contact relates negatively to prejudice in both majority and minority members. 
However, previous work has found reciprocal effects between contact and intergroup attitudes. For example, contacts predict prejudice negatively, while negative intergroup attitudes lead to fewer contacts (Pettigrew, 2008). Longitudinal investigation has also showed a bidirectional relationship between contact and prejudice (Binder et al., 2009). In the present study we explore whether a preference for assimilation, integration and a more positive attitude towards the majority members will predict more contact.

The third objective is to examine the multiculturalism hypothesis, which proposes that confidence in one's identity underlies the possibility of accepting "others" (Berry \& Ward, 2016). This confidence involves a sense of security, or conversely a sense of threat. When migrants' identity is threatened, they will develop rejection of others (Berry, 1984).

In a previous paper the multiculturalism hypothesis has been tested using cultural security (Neto, in press). In the current study we are going to test this hypothesis using perceived discrimination. Experiences of discrimination are one factor of the major stressors associated with intercultural problems among migrants (van Geel \& Vedder, 2009; Neto, Pinto, \& Mullet, 2019). Previous investigation has shown that perceived discrimination was associated with poor psychological well-being (Pascoe and Smart Richman, 2009; Lee \& Ahn, 2011; Schmitt, Branscombe, Postmes, \& Garcia, 2014; Suh, Flores, \& Wang, 2019). Perceived discrimination has also been shown to be a detrimental factor for self-acceptance among Romanian immigrants in Spain (Fernândez, Silván-Ferrero, P., Molero, F., Gaviria, E., \& Garcia-Ael, 2015). The subjective interpretation of events as discriminatory is likely to be negatively associated with the acceptance of others.

When migrants are threatened, namely by the perception of discrimination, on the one hand they will prefer separation and marginalization strategies (both based on lack of involvement with other groups in the host society), and on the other hand they will evidence low level of tolerance, negative attitudes towards the members of the host society and towards other migrants (all involving rejection of others).

\section{Research hypotheses}

Based upon the review of the relevant literature presented above, the following hypotheses were advanced:

1 The integration hypothesis: immigrants who prefer the integration reveal higher adaptation. Specifically:

$\mathrm{H}_{1}$ Higher integration strategy would predict higher psychological adaptation, sociocultural adaptation, and intercultural adaptation.

2 The intercultural contact hypothesis: the higher intercultural contact, the higher mutual acceptance. Specifically:

$\mathrm{H}_{2}$ Higher positive attitude toward Portuguese, assimilation and integration would predict higher intercultural contact.

3 The multiculturalism hypothesis: the higher immigrants' perceived discrimination, the lower is their propensity to accept people culturally different. Specifically:

$\mathrm{H}_{3}$ Higher perceived discrimination would be associated with lower tolerance, attitude towards Portuguese, attitude towards other immigrants, and higher preference for separation and marginalization.

\section{Method}

\section{Participants}

Participants were 218 Ukrainian migrants (153 men, 61 women, and 4 did not indicate their gender) whose ages ranged from 20 to 60 years $(M=38.76 ; S D=9.46)$. The average length of residence in Portugal was 10 years $(S D=4.99)$. Participants who were married constituted $82 \%$ of the sample. As regards employment, the modal category was skilled work (51\%). In terms of education, $11 \%$ had not concluded secondary education, 25\% had concluded secondary education, and 65\% attended tertiary education. 


\section{Table 1}

Socio-demographic characteristics of the Ukrainian immigrants $N=218$

\begin{tabular}{lr}
\hline \multicolumn{1}{c}{ Characteristic } & \multicolumn{1}{c}{$\begin{array}{r}\text { Ukrainians } \\
(\%)\end{array}$} \\
\hline Mean age (SD) & $38.78(9.46)$ \\
Gender & $153(70.2)$ \\
Male & $61(28.0)$ \\
Female & $4(1.8)$ \\
Not answered & $10.27(4.99)$ \\
Mean years in Portugal (SD) & \\
Marital status & $178(81.7)$ \\
Married & $40(18.3)$ \\
Not Married & \\
Level of education & $24(11.0)$ \\
Less than secondary school & $54(24.8)$ \\
Secondary school & $140(64.2)$ \\
Tertiary education & \\
Work & $56(25.7)$ \\
Unskilled work & $111(50.9)$ \\
Skilled work & $26(11.9)$ \\
Managerial work & $2(0.9)$ \\
Professional work & $23(10.6)$ \\
Without work & \\
Religion & $4(1.8)$ \\
No religion & $69(31.7)$ \\
Orthodox Catholics & $3(1.4)$ \\
Roman Catholic & $8(3.6)$ \\
Protestant & \\
Other &
\end{tabular}

\section{Measures}

This research employed some scales from the "Mutual Intercultural Relations in Plural Societies" (MIRIPS) project (Berry, 2017). These scales have been translated into Portuguese and adapted for use in Portugal in former international projects (International Comparative Study of Ethnocultural Youth ICSEY- Berry, Phinney, Sam, \& Vedder, 2006; Neto, 2006; and International Study of Attitudes Towards Immigration and Settlement -ISATISBerry \& Kalin, 1995; Neto, 2009). In this study we used five response options from 1 "strongly disagree" to 5 "strongly agree", but the measurement of attitudes towards nationals and immigrants.

Acculturation strategies. Grounded on the Acculturation Attitudes Scale (Berry, Power, Young, \& Bujaki, 1989; see also Neto, 2002) we measured acculturation strategies with a 20 - item scale. The scale assesses four acculturation strategies: assimilation, integration, separation, and marginalization. Each acculturation strategy was measured with five items assessing five domains of life: culture traditions, languages, social activities, friends, and music. A sample item was "I prefer social activities which involve Portuguese only".

Intercultural contacts. To assess intercultural contacts of immigrants with native Portuguese we asked participants the number of close friends and frequency of contact with them (e.g., "How often do you meet with Portuguese people?") (Neto \& Fonseca, 2016).

Attitudes towards nationals. The "feeling thermometer" was used to assess attitudes towards nationals. It is a 10-point scale used to indicate the favourability toward Portuguese $(0=$ extremely unfavourable, $10=$ extremely favourable).

Attitudes towards other immigrants. The "feeling thermometer" was also used to assess attitudes towards 17 groups of other immigrants, such as, Brazilians, Indians, Mozambicans, and Timorese. A 10-point scale was used to indicate the favourability toward those immigrants $(0$ $=$ extremely unfavourable, $10=$ extremely favourable).

Perceived Discrimination. Perceived discrimination was assessed using five items about the direct experience of discrimination (e.g., "I don't feel accepted by the Portuguese.") (Berry et al., 2006; Neto, 2006; Neto \& Wilks, 2017).

Sociocultural adaptation. The Sociocultural Adaptation Scale (SCAS, Ward \& Kennedy, 1999; Sequeira Neto, 2014) asked respondents the degree of difficulty experienced in 20 social situations in the host society (e.g., "The pace of life" and "Going to social gatherings"). Higher scores denoted a lower amount of difficulty.

Tolerance. This scale includes 11 items (Berry, 2006; Berry \& Kalin, 1995; Neto, 2009) measuring both one's ethnic tolerance (6 items; e.g., "It is good to have people from different ethnic groups living in the same country"), and social egalitarianism (5 items; e. g., "If people 
FÉlix Neto.

were treated more equally we would have fewer problems in this country").

Self-Esteem. Self-esteem was assessed using Rosenberg's (1986) 10-item self-esteem inventory (e.g., "On the whole I am satisfied with myself" and "I have a positive attitude toward myself").

Demographic information. Information was collected on age, gender, place of birth, both parents place of birth, time since arrival in the society of settlement, level of education, and current occupation.

\section{Procedure}

The data were collected by two trained research assistants in the Greater Metropolitan Lisbon. The participants were contacted in places where they meet: communities, clubs, and parishes. The response rate was $80 \%$. Participants were informed about the aim of the research, the voluntariness of participation, and they provided informed consent. The questionnaires were administered in Portuguese. The average time for filling out the questionnaire was 30 minutes. The anonymity of the responses was guaranteed.

\section{Results}

Preliminary analyses were performed to scrutinize the psychometric properties of the instruments used. Descriptive statistics and reliability coefficients of the instruments used in this research are shown in Table 2. Cronbach alphas were estimated to check scalar reliability of the scales containing multiple items. The Cronbach alpha reliability coefficients for the measures showed acceptable internal consistency.
Table 2

Means, standard deviations, and reliability coefficients of the measures for the Ukrainian immigrants

\begin{tabular}{lllcc}
\hline \multicolumn{1}{c}{ Variables } & $M$ & $S D$ & Items & Cronbach's $\alpha$ \\
\hline Integration & 3.37 & 0.92 & 5 & 0.71 \\
Assimilation & 2.63 & 0.84 & 5 & 0.79 \\
Separation & 2.56 & 0.85 & 5 & 0.71 \\
Marginalization & 2.15 & 0.81 & 5 & 0.80 \\
Intercultural contacts with home members & 3.91 & 0.89 & 2 & 0.77 \\
Attitude towards home members & 8.59 & 2.01 & 1 & \\
Attitude towards other immigrants & 6.02 & 2.04 & 17 & 0.95 \\
Perceived discrimination & 2.48 & 1.04 & 5 & 0.87 \\
Sociocultural adaptation & 3.77 & 0.95 & 20 & 0.96 \\
Tolerance & 3.78 & 0.62 & 11 & 0.74 \\
Self-esteem & 3.69 & 0.70 & 10 & 0.76 \\
\hline
\end{tabular}

One-sample $t$ tests displayed that the mean score of the integration strategy $(M=3.37)$ was significantly greater than the midpoint (3) of the scale $(p<0.001)$. Also, mean scores of assimilation, separation, and marginalization were significantly smaller than the midpoint of the scales (all $p<0.001$ ). An inspection of these average scores showed two groupings among Ukrainian immigrants: on the on hand, the integration strategy was on the preferred side; on the other hand, the other three acculturation strategies were not preferred.

Hierarchical multiple regressions were performed to predict the three kinds of adaptation (see Table 3). Before conducting the regression analyses, collinearity diagnostics was examined to ensure that the variance inflation factor did not exceed 10. This will be done in all multiple regressions which will next be conducted. To control for the possible confounding effects of age and gender, they were entered in the first block. The four intercultural strategies were entered in the second block. It has been used self-esteem, as indicator of psychological adaptation as we have said above. For this sample, the regression showed that $29 \%$ of the total variance in psychological adaptation could be explained by independent variables, $F(6,196)=13.35, p<0.001$. Psychological adaptation was positively predicted by integration $(\beta=0.21, p<0.01)$ and assimilation $(\beta=0.26, p<0.01)$, and negatively predicted by marginalization $(\beta=-0.56, p<$ 0.001).

As regards sociocultural adaptation, the regression showed that $15 \%$ of the total variance 
could be explained by independent variables, $F(6,185)=5.31, p<0.001$. Sociocultural adaptation was negatively predicted by marginalization $(\beta=-0.24, p<0.001)$.

Finally, we have considered tolerance, as indicator of intercultural adaptation. The regression showed that $33 \%$ of the total variance in tolerance could be explained by independent variables, $F(6,188)=15.35, p<0.001$. Intercultural adaptation was positively predicted by integration $(\beta=0.34, p<0.001)$, and negatively predicted by assimilation $(\beta=-0.32$, $p<0.001)$ and separation $(\beta=-0.30, p<$ $0.001)$. These results support partially our first hypothesis.

Table 3

The results of the hierarchical regression analyses $(\beta)$ on the predictors of adaptation outcomes

\begin{tabular}{|c|c|c|c|c|c|c|}
\hline \multirow[t]{2}{*}{ Variables } & \multicolumn{2}{|c|}{$\begin{array}{c}\text { Psychological } \\
\text { adaptation }\end{array}$} & \multicolumn{2}{|c|}{$\begin{array}{c}\text { Sociocultural } \\
\text { adaptation }\end{array}$} & \multicolumn{2}{|c|}{$\begin{array}{c}\text { Intercultural } \\
\text { adaptation }\end{array}$} \\
\hline & Block 1 & Block 2 & Block 1 & Block 2 & Block 1 & Block 2 \\
\hline Age & 0.02 & -0.05 & -0.04 & -0.07 & -0.02 & -0.04 \\
\hline Gender & 0.07 & 0.01 & 0.01 & 0.01 & 0.03 & 0.08 \\
\hline Integration & & $0.21 * *$ & & 0.08 & & \\
\hline Assimilation & & $0.26^{* *}$ & & -0.13 & & \\
\hline Separation & & -0.07 & & -0.08 & & \\
\hline Marginalization & & $-0.56 * * *$ & & $-0.24 *$ & & \\
\hline$R^{2}$ & 0.01 & 0.29 & 0.01 & 0.15 & 0.02 & 0.33 \\
\hline Adjusted $R^{2}$ & -0.01 & 0.27 & -0.01 & 0.12 & 0.01 & 0.31 \\
\hline$F$ change & 0.47 & $19.69 * * *$ & 0.14 & $7.78^{* * *}$ & 1.69 & $21.43^{* * *}$ \\
\hline Age & 0.02 & -0.05 & -0.04 & -0.07 & -0.02 & -0.04 \\
\hline
\end{tabular}

Hierarchical multiple regressions were also performed to predict intercultural contact. Age and gender were entered in the first block. Assimilation, integration and attitude toward Portuguese were entered in the second block. The regression showed that $20 \%$ of the total variance in intercultural contact could be explained by independent variables, $F(5,188)=$ 9.30, $p<.001$. The effects of age, assimilation, and attitude toward Portuguese were significant. Intercultural contact was positively predicted by age $(\beta=0.19, p<0.01)$, assimilation $(\beta=0.31$, $p<0.001)$, and attitude toward Portuguese $(\beta$ $=0.16, p<0.05)$. However, integration did not emerge as a significant predictor of intercultural contact. These results confirm partially our second hypothesis.
Table 4

The results of the hierarchical regression analyses $(\beta)$ on the predictors of intercultural contact

\begin{tabular}{|c|c|c|}
\hline \multirow[b]{2}{*}{ Variables } & \multicolumn{2}{|c|}{ Cultural security } \\
\hline & Block 1 & Block 2 \\
\hline Age & $0.18^{*}$ & $0.19 * *$ \\
\hline Gender & -0.10 & -0.07 \\
\hline Integration & & -0.10 \\
\hline Assimilation & & $0.31 * * *$ \\
\hline Attitude towards home members & & $0.16^{*}$ \\
\hline$R^{2}$ & 0.05 & 0.20 \\
\hline Adjusted $R^{2}$ & 0.04 & 0.18 \\
\hline$F$ change & $11.77 * *$ & $11.77 * *$ \\
\hline
\end{tabular}

As regards the third objective, to test the multiculturalism hypothesis we used the construct of perceived discrimination which is the opposite of feelings of security. Onesample $t$ test displayed that the mean score of perceived discrimination $(M=2.48)$ was significantly below the midpoint (3) of the scale $(p<0.001)$. Hence, these results indicate that Ukrainian immigrants perceived little discrimination from the host society. Pearson product-moment correlations were computed between perceived discrimination, and tolerance, attitude towards Portuguese, attitude towards other immigrants, separation and marginalization. As predicted, perceived discrimination was negatively associated with tolerance $(r=-0.22, p<0.01)$, attitude towards Portuguese $(r=-0.14, p<.05)$, attitude towards other immigrants $(r=-0.18$, $p<0.05)$, while separation $(r=0.14, p<$ $0.05)$, and marginalization $(r=0.56, p<$ 0.001 ) were positively associated with perceived discrimination. These results support hypothesis 3.

\section{Discussion}

This study set out to test three hypotheses derived from theoretical propositions on interethnic relations in multicultural societies (Berry, 2013; 2017) among Ukrainian immigrants living in Portugal. The participants in this study showed a preference for the integration strategy. In agreement with expectations the 
integration strategy was significantly associated with psychological adaptation (Abu-Raya \& Sam, 2016; Ward \& Geeraert, 2016). This finding is consonant with a meta-analytic study which displayed that integration was linked to psychological adaptation (e.g., life satisfaction, positive affect, and self-esteem) (Nguyen \& Benet-Martinez, 2013). This meta-analysis evidenced also a link between biculturalism and sociocultural adaptation (e.g., academic achievement, career success, social skills, lack of behavioural problems). Our study did not support this link as sociocultural adaptation was not predicted by integration, but by marginalization. A similar result was also found among Cape Verdean immigrants living in Portugal (Neto, in press). A possible explanation for this finding may be related to the length of residence abroad. The average duration of stay of our sample in Portugal was 10 years. Wilson, Ward, and Fisher (2013) concluded that "sociocultural adaptation difficulties have been found to be greatest on arrival to a new culture and decrease predictably over time" (p. 901). Indeed, there is research suggesting that the positive relations between integration and sociocultural adaptation is observed in the short-term following emigration, but not later (Jasinskaja-Lahti, Horenczyk, \& Kinunen, 2011).

Nevertheless, the relationship expected between the integration strategy and intercultural adaptation was confirmed. Intercultural adaptation was predicted by greater integration. Hence, the present research contributed to expand the integration hypothesis to a recent proposed kind of adaptation. The positive link between integration and the outcomes of acculturation can be explained by the "doubly engagement" with both cultures (Berry, 2017). In this case people receive support and resources from both cultures and reveal competence in dealing with them.

As regards the contact hypothesis, we explored the relationships between intercultural contacts and intergroup attitudes. We used as indicators of intergroup attitudes two acculturation strategies, integration and assimilation, and attitude toward the members of the host society. The hypothesis tended to be supported as higher assimilation and positive attitude towards the members of the society of settlement predicted intercultural contacts. However, integration was not significantly related to intercultural contact. Overall, the findings are in agreement with past research which showed a relationship between intergroup contacts and positive intergroup attitudes among minority groups (Pettigrew, 2008).

We analysed how immigrants felt they were treated by the society of settlement. In general, Ukrainians did perceive a relatively low discriminatory treatment. As regards the multiculturalism hypothesis we analysed the relationships between perceived discrimination, and tolerance, attitude towards Portuguese, attitude towards other immigrants, separation and marginalization. As expected, the data found support to the multiculturalism hypothesis (Berry \& Ward, 2016). (On one hand, perceived discrimination was associated with lower tolerance and negative attitudes towards the members of the host society and towards other immigrants; on the other hand, perceived discrimination was associated with a preference for separation and marginalization strategies.

A relevant limitation of the current research concerns the data-collection process. In this regards, our findings should be replicated with measures which are not based only on selfreports. In addition, the causal direction needs to be approached by longitudinal and experimental works. Nevertheless, our results do highlight the importance of the core conditions for positive intercultural relations among Ukrainians in Portugal: the promotion of integration strategy, friendly intercultural contacts, and low level of perceived discrimination.

\section{References}

Abu-Raya, H. M., \& Sam, D. L. (2016). Is integration the best way to acculturate? A reexamination of the bicultural-adaptation relationship in the "ICSEY" data set" using the bilinear method. Journal of Cross- 
Cultural Psychology, 48(3), 287-293. https:/ /doi.org/10.1177/0022022116685846

Allport, G. W. (1954). The nature of prejudice. Reading, MA: Addison-Wesley.

Berry, J. W. (1997). Immigration, acculturation and adaptation. Applied Psychology: An International Review, 46(1), 5-68. https://do i.org/10.1111/j.1464-0597.1997.tb01087.x

Berry, J. W. (1984). Multicultural policy in Canada: A social psychological analysis. Canadian Journal of Behavioral Science, 16(3), 353-370. https://doi.org/10.1037/h0 080859

Berry, J. W. (2006). Mutual attitudes among immigrants and ethnocultuaal groups in Canada. International Journal of Intercultural Relations, 30(6), 719-734. https://doi.org/10 $.1016 /$ j.ijintrel.2006.06.004

Berry, J. W. (2013). Research on multiculturalism in Canada. International Journal of Intercultural Relations, 37(6), 663-675. http s://doi.org/10.1016/j.ijintrel.2013.09.005

Berry, J. W. (2015). Intercultural adaptation to acculturation. Paper presented at Annual Conference, Canadian Psychological Association, Ottawa, June.

Berry, J. W. (2017). Mutual intercultural relations in plural societies. Cambridge: Cambridge University Press. https://doi.org/10.1017/97 81316875032

Berry, J. W., Power, S., Young, M., \& Bujaki, M. (1989). Acculturation attitudes in plural societies. Applied Psychology: An International Review, 38(2), 185-206. https://doi.org/10.1111/j.1464-05 97.1989.tb01208.x

Berry, J. W., \& Kalin, R. (1995). Multicultural and ethnic attitudes in Canada: An overview of the 1991 national survey. Canadian Journal of Behavioural and Science, 27(3), 301-320. https://doi.org/10.1037/00 08-400X.27.3.301

Berry, J. W., \& Sabatier, C. (2010). Acculturation, discrimination, and adaptation among second generation immigrant youth in Montreal and Paris. International Journal of Intercultural Relations, 34(3), 191-207. http s://doi.org/10.1016/j.ijintrel.2009.11.007
Berry, J. W., \& Ward, C. (2016). Acculturation. In D. Sam \& J. W. Berry (Eds.), The Cambridge handbook of acculturation psychology (2nd ed., pp. 441-463). Cambridge: Cambridge University Press.

Berry, J. W., Phinney, J. S., Sam, D. L., \& Vedder, P. (Eds.) (2006). Immigrant youth in cultural transition: Acculturation, identity and adaptation across national contexts. Mahwah: Lawrence Erlbaum Associates. https://doi.o $\mathrm{rg} / 10.4324 / 9780415963619$

Binder, J., Zagefka, H., Brown, R., Funke, F., Kessler, T., Mummendy, A., ... Lyens, J. P. (2009). Does contact reduce prejudice or does prejudice reduce contact. A longitudinal test of the contact hypothesis among majority and minority groups in three European countries. Journal of Personality and Social Psychology, 96(4), 843-856. https://doi.org/10.1037/a0013470

Brown, C. M., Gibbons, J. L., \& Hughes, H. M. (2013). Acculturation clusters and life satisfaction. Acta de Investigación Psicológica, 3(2), 1108-1121. https://doi.org/10.1016/S 2007-4719(13)70955-4

Coopersmith, S. (1967). The antecedents of selfesteem. San Francisco: W. H. Freeman.

Fernândez, I., Silván-Ferrero, P., Molero, F., Gaviria, E., \& Garcia-Ael, C. (2015). Perceived discrimination and well-being in Romanian immigrants: The role of social support. Journal of Happiness Studies, 16, 857-870. https://doi.org/10.1007/s10902-0 $14-9537-0$

Furnham, A., \& Bochner, S. (1986). Culture shock: Psychological reactions to unfamiliar environments. London: Methuen.

Jasinskaja-Lahti, I., Horenczyk, G., \& Kinunen, T. (2011). Time and context in the relationship between acculturation attitudes and adaptation among Russiaspeaking immigrants in Finland and Israel. Journal of Ethnic and Migration Studies, 37(9), 1423-1440. https://doi.org/10.1080/ 1369183X.2011.623617

Lee, D. L., \& Ahn, S. (2011). Discrimination against Latina/os: A meta-analysis of individual-level resources and outcomes. 
FÉLIX Neto.

The Counseling Psychologist, 40(1), 28-65. h ttps://doi.org/10.1177/0011000011403326

Marques, J., \& Góis, P. (2008). Imigrantes altamente qualificados em Portugal: uma tipologia. Migrações, 2, 73-94. https://pdfs.semanticscholar.org/99 5a/ef022e9115056907a972b06e93a8f9ae2 c21.pdf

Neto, F. (2002). Acculturation strategies among adolescents from immigrant families in Portugal. International Journal of Intercultural Relations, 26(1), 17-38. https:// doi.org/10.1016/S0147-1767(01)00036-0

Neto, F. (2006). Psycho-social predictors of perceived discrimination among adolescents of immigrant background: A Portuguese study. Journal of Ethnic and Migration Studies, 32(1), 89-109. https://doi .org/10.1080/13691830500335507

Neto, F. (2009). Are attitudes of young Portuguese towards immigration also hardening? A comparison between 1999 and 2006. In A. Gari \& K. Mylonas (Eds.), Quod erat demonstrandum: From Herodotus' ethnographioc journeys to crosscultural research (pp. 255- 264). Athens: Pedio Books Publishing.

Neto, F. (2010). Portugal intercultural: Aculturação $e$ adaptação de jovens de origem imigrante. Porto: Livpsic.

Neto, F. (2019). Acculturation, adaptation and saudade among Portuguese migrants. The Journal of Psychology, 153(7), 667-679. https://doi.org/10.1080/00223980 .2019 .1590298

Neto, F. (in press). Intercultural relations among Cape Verdean immigrants living in Portugal. Journal of International Migration and Integration, https://doi.org/10.1007/s12 134-019-00679-8

Neto, F., \& Fonseca, A. C. (2016). The Satisfaction with Migration Life Scale. International Journal of Intercultural Relations, 54, 47-54. https://doi.org/10.1016 /j.ijintrel.2016.07.004

Neto, F., Pinto, M. C., \& Mullet, E. (2019). Can music reduce national prejudice? A test of a cross-cultural musical education programme. Psychology of Music, 47(5), 747-756. https://doi.org/10.1177/03057356 18774867

Neto, F., \& Wilks, D. (2017). Predictors of psychological adaptation of Cape Verdean students in Portugal. Journal of College Student Development, 58(7), 1087-1100. htt ps://doi.org/10.1353/csd.2017.0085

Neto, F., Wilks, D. C., \& Fonseca, A. (2019). Job-related well-being of immigrants. Social Indicators Research, 141, 463-465. https://d oi.org/10.1007/s11205-018-1849-8

Nguyen, A. M., \& Benet-Martinez, V. (2013). Biculturalilsm and adjustment: A meta-analysis. Journal of Cross-Cultural Psychology, 44(1), 122-159. https://doi.org/ 10.1177/0022022111435097

Orthy, U., \& Robins, R. W. (2014). The development of self-esteem. Current Directions in Psychological Science, 23(5), 381-387. https://doi.org/10.1177/09637214 14547414

Pascoe, E. A., \& Smart Richman, L. (2009). Perceived discrimination and health: A meta-analytic review. Psychological Bulletin, 135(4), 531-554. https://doi.org/10.1037/a 0016059

Pettigrew, T. F. (2008). Future directions for intergroup contact theory and research. International Journal of Intercultural Relations, 32(3), 187-199. https://doi.org/10 $.1016 /$ j.ijintrel.2007.12.002

Pettigrew, T. F., \& Tropp, L. R. (2006). A metaanalytic test of intergroup contact theory. Journal of Personality and Social Psychology, 90(5), 751-783. https://doi.org/10.1037/00 22-3514.90.5.751

Pettigrew, T., \& Tropp, L. (2011). When groups meet. London: Psychology Press.

Recker, C., Milfont, T. L., \& Ward, C. (2017). A dual-process motivational model of acculturation behaviors and adaptation outcomes. Universitas Psychologica, 1-15. 16(5). https://doi.org/10.11144/Javeriana.u psy16-5.dmma

Rosenberg, M. (1986). Conceiving the self. Melbourne: Krieger. 
Rosenberg, M., \& Kaplan, H. B. (1982). Social psychology of the self-concept. Arlington Heights, IL: Harlan Davidson.

Sam, D. L., \& Berry, J. W. (2010). Acculturation: When individuals and groups of different cultural backgrounds meet. Perspectives on Psychological Science, 5(4), 472-481. https:// doi.org/10.1177/1745691610373075

Sam, D. L., \& Berry, J. W. (2016). The Cambridge handbook of acculturation psychology $\left(2^{\text {nd }}\right.$ ed.). Cambridge: Cambridge University Press. https://doi.org/10.1017/CBO978131 6219218

Schmitt, M. T., Branscombe, N. R., Postmes, T., \& Garcia, A. (2014). The consequences of discrimination for psychological wellbeing: A meta-analytic review. Psychological Bulletin, 140, 921-948. https://doi.org/10.10 37/a0035754

Sequeira Neto, J. (2014). Cultural competence among Ukrainian economic immigrants living in Portugal (Unpublished master dissertation). Faculdade de Economia: Universidade do Porto, Portugal.

Serviço de Estrangeiros e Fronteiras (SEF). (2015). Relatório de Imigração, Fronteira e Asilo 2014. Lisboa: SEF.

Suh, H. N., Flores, L. Y., \& Wang, K. T. (2019). Perceived discrimination, ethnic identity, and mental distress among Asian international students in Korea. Journal of Cross-Cultural Psychology, 50(8), 991-1007. https://doi.org/10.1177/0022022 119874433

van Geel, M., \& Vedder, P. (2009). Peceived discrimination and psychological adjustment of immigrants: A review of research. In I. Jasinskaja-Lahti \& T. A. Mähönen (Eds.), Identities, intergroup relations and acculturation: The cornerstones of intercultural encounters. Helsinki: Helsinki University Press.

Ward, C., \& Geeraert, N. (2016). Advancing acculturation theory and research: The acculturation process in its ecological context. Current Opinion in Psychology, 8, 98-104. https://doi.org/10.1016/j.copsyc.20 15.09.021
Ward, C., \& Kennedy, A. (1999). The measurement of sociocultural adaptation. International Journal of Intercultural Relations, 23(4), 659-677. https://doi.org/10 .1016/S0147-1767(99)00014-0

Ward, C., \& Rana-Deuba, A. (1999). Acculturation and adaptation revised. Journal of Cross-Cultural Psychology, 30(4), 422-442. https://doi.org/10.1177/00220221 99030004003

Ward, C., Bochner, S., \& Furnham, A. (2001). The psychology of culture shock ( $2^{\text {nd }}$ ed.). Hove, UK: Routledge.

Wilson, J., Ward, C., \& Fisher, R. (2013). Beyond culture learning theory: What can personality tell us about cultural competence? Journal of Cross-Cultural Psychology, 44(6), 900-927. https://doi.org/ 10.1177/0022022113492889

Wylie, R. (1979). The self-concept. Lincoln: University of Nebraska Press.

Zhou, S., Page-Gould, E., Aron, A., Moyer, A., \& Hewstone, M. (2019). The extended contact hypothesis: A meta-analysis on 20 years of research. Personality and Social Psychology Review, 23(2), 132-160. https://d oi.org/10.1177/1088868318762647

\section{Notes}

* Research article. 